\title{
Karakteristik Mikrobiologi dan Fisikokimia Dendeng Sapi yang Ditambahkan Simplisia Serbuk Jahe Merah
}

\author{
Rifkhan $^{1, a}$, Tuti Suryati, ${ }^{2, a}$, Irma Isnafia Arief ${ }^{2}$ \\ ${ }^{1}$ Program Studi Ilmu Produksi dan Teknologi Peternakan, Fakultas Peternakan, Sekolah Pascasarjana \\ Institut Pertanian Bogor \\ ${ }^{2}$ Departemen Ilmu Produksi dan Teknologi Peternakan, Fakultas Peternakan IPB \\ J1. Agatis Kampus IPB Darmaga, Bogor 16680 \\ aemail: rifkhan_han@apps.ipb.ac.id, tutisuryati16@gmail.com
}

\begin{abstract}
Abstrak
Dendeng adalah produk olahan pangan dari daging dengan penambahan bumbu tradisional dan dikeringkan, banyak yang mengolahnya dengan variasi penambahan bumbu khusus, salah satunya dengan penambahan simplisia serbuk jahe merah. Penelitian ini bertujuan untuk menganalisis pertumbuhan mikroba dan kualitas fisikokimia dari dendeng sapi yang ditambahkan simplisia serbuk jahe merah pada level yang berbeda. Variabel yang diamati yaitu karakteristik mikrobiologi (total bakteri, total Escherichia coli, dan total Staphylococcus aureus), karakteristik fisikokimia ( $\mathrm{pH}$, aktifitas air, kadar malonaldehida dan antioksidan). Rancangan penelitian menggunakan rancangan acak kelompok 5 perlakuan dan 3 ulangan dengan penambahan persentase pemberian simplisia serbuk jahe merah sebesar $0 \%, 5 \%, 10 \%, 15 \%$, dan 20\%. Hasil penelitian menunjukkan berbeda nyata pada pengujian TPC $(\mathrm{P}<0,05)$ dengan penurunan jumlah bakterinya, sedangkan hasil pengujian Escherichia coli dan Staphylococcus aureus tidak terdapat pada setiap perlakuan, kemudian hasil pengujian fisikokimia menunjukkan hasil yang berbeda nyata $(\mathrm{P}<0,05)$ pada pengujian $\mathrm{pH}$, aktifitas air, malonaldehida, dan antioksidan pada setiap perlakuannya. Pada keseluruhan perlakuan dendeng sapi yang ditambahkan simplisia serbuk jahe merah sampai level penambahan $20 \%$ masih aman untuk dikonsumsi.
\end{abstract}

Kata kunci: dendeng, simplisia serbuk jahe merah, fisikokimia, mikrobiologi.

Characteristics of Microbiology and Physicochemical Food Dried Cow (Dendeng) Added by Simplician Powder of Red Ginger

\begin{abstract}
Dendeng is a processed food product from meat with the addition of traditional spices and dried, many of which process it with variations in the addition of special seasonings, one of which is by adding simplicia red ginger powder. This study aims to analyze the microbial growth and physicochemical quality of dendeng added with simplicia red ginger powder at different levels. The observed variables were microbiological characteristics (total bacteria, total Escherichia coli, and total Staphylococcus aureus), physicochemical characteristics ( $\mathrm{pH}$, water activity, malonaldehyde levels and antioxidants). The study design used a randomized 5 treatment group design and 3 replications with the addition of the percentage of red ginger powder simplicia by 0\%, 5\%, 10\%, 15\%, and 20\%. The results showed significantly different in total bacteria testing $(P<0.05)$ with a decrease in the number of bacteria, while the results of Escherichia coli and Staphylococcus aureus testing were not found in each treatment, then the results of physicochemical testing showed significantly different results $(P<0.05)$ in testing $p H$, water activity, malonaldehyde, and antioxidants in each treatment. In the overall treatment of dendeng were added with simplicia red ginger powder until the level of the addition 20\% is still safe for consumption.
\end{abstract}

Keywords: dendeng, simplicia red ginger powder, physicochemical, microbiology. 


\section{Pendahuluan}

Daging merupakan produk hasil peternakan yang dikonsumsi oleh masyarakat Indonesia, menurut data Direktorat Jenderal Peternakan dan Kesehatan Hewan Kementerian Pertanian Republik Indonesia (2017) konsumsi daging sapi per kapita tahun 2017 sebesar 0,469 $\mathrm{kg}$, atau meningkat sebesar 12,50 persen dari konsumsi daging sapi per kapita tahun 2016 sebesar $0,417 \mathrm{~kg}$ sedangkan konsumsi daging ayam ras per kapita tahun 2017 sebesar 5,683 $\mathrm{kg}$, atau mengalami peningkatan sebesar 11,22 persen dari konsumsi tahun 2016 sebesar 5,110 $\mathrm{kg}$. Hal tersebut menjadikan daging sebagai salah satu sumber produk pangan yang dikonsumsi oleh masyarakat Indonesia. Oleh karena itu banyak diantara masyarakat mengolah daging menjadi produk olahan pangan yang siap dikonsumsi, salah satu produk olahan daging di Indonesia adalah dendeng.

Menurut Suryati et al. (2014) dendeng adalah daging kering khas tradisional Indonesia, umumnya diproduksi dengan menggunakan beberapa bumbu dan gula dengan rasa yang manis dan pedas, dan stabil selama beberapa minggu pada suhu kamar. Dendeng juga merupakan salah satu jenis makanan yang menerapkan teknologi pengeringan untuk mengurangi kadar air dalam bahan pangan sampai dianggap cukup aman untuk menekan pertumbuhan dan perkembangbiakan bakteri (Suradi et al., 2017). Melalui pengeringan yang menghasilkan pengurangan kadar air, masa simpan dendeng dapat lebih lama dibandingkan dengan masa penyimpanan pada daging segar. Selain dengan pengeringan, masa simpan dendeng dapat diperpanjang dengan penambahan bumbu dan rempah yang memiliki aktivitas antioksidan dan antimikroba, salah satu bumbu tradisional yang dapat digunakan adalah jahe.

Penelitian dengan penggunaan jahe pada produk peternakan lebih banyak menggunakan rimpang. Penelitian dengan menggunakan simplisia serbuk jahe khususnya penggunaan simplisia serbuk jahe merah pada produk peternakan jarang dilakukan, demikian pula penggunaan simplisia serbuk jahe merah pada produk olahan daging seperti dendeng. Menurut definisi simplisia dan serbuk sangatlah berbeda, simplisia adalah bahan alam obat tradisional yang telah dikeringkan yang digunakan untuk pengobatan dan belum mengalami pengolahan sedangkan serbuk simplisia adalah sediaan obat tradisional berupa butiran homogen dengan derajat halus yang sesuai (Sulistyani, 2018). Oleh karena itu penulis tertarik untuk melakukan penelitian pada dendeng dengan meninjau dari nilai mikrobiologi dan fisikokimia yang diberikan simplisia serbuk jahe merah pada level yang berbeda.

\section{Materi dan Metode \\ Materi Penelitian}

Bahan yang akan digunakan dalam penelitian ini mengacu pada Suryati et al. (2014). Bahan dimodifikasi dengan penambahan simplisia serbuk jahe merah yang tersaji pada tabel 1 (Formulasi Pembuatan Dendeng dengan Penambahan Simplisia Serbuk Jahe Merah). Daging sapi segar didapatkan dari pasar tradisional di wilayah Kota Bogor, sedangkan bahan pembuatan simplisia serbuk jahe merah terdiri atas jahe merah yang didapatkan dari pasar lokal disekitar wilayah Kota Bogor, yang kemudian dikeringkan menjadi simplisia untuk dijadikan olahan bubuk. Gao dan Zhang (2010) mengemukakan bahwa jahe kering disimplisiasikan dengan memproses menjadi serbuk. Penggunaan simplisia serbuk jahe merah disesuaikan dengan jumlah formula dalam pembuatan dendeng dengan masingmasing persentase sebesar $0 \%, 5 \%, 10 \%, 15 \%$, dan $20 \%$ dari total kebutuhan formula pembuatan dendeng.

Bahan untuk analisis mikrobiologi terdiri atas buffer pepton water (BPW), plate count agar (PCA), eosin methilen blue agar (EMBA), bairt parker agar (BPA), kalium tellurit dan akuades. Pengujian aktivitas fisikokimia menggunakan bahan untuk analisis malonaldehida yang terdiri atas propylgalate (PG), ethylene diaminete traacetic acid (EDTA), asam klorida (HCl), antibusa, tiobarbituric acid (TBA), dan tetra ethoxy propane (TEP). Bahan untuk pengujian antioksidan dan total fenol adalah metanol, pereaksi folin-ciocalteu, pereaksi natrium karbonat, pereaksi asam galat, dan diphenyl picrylhydrazil (DPPH). Peralatan yang digunakan dalam penelitian ini terdiri atas spektrofotometer (GeneQuant 1300, swedan), $\mathrm{pH}$ meter (Hanna Intrument,USA), dan $\mathrm{a}_{\mathrm{w}}$ meter (Novasiana, Swistzerland). 


\section{Metode Penelitian}

Pembuatan simplisia serbuk jahe merah yang diawali dengan membersihkan dari kotoran yang menempel melalui pencucian dengan air bersih, kemudian di potong-potong menjadi ukuran lebih kecil sebesar 3-5 mm dan dikeringkan dengan cara dikering anginkan untuk dijadikan simplisia. Jahe merah yang telah menjadi simplisia kemudian digiling halus menjadi serbuk, seperti yang dikemukakan oleh Sulistyani (2018).

Proses pembuatan dendeng mengikuti Suryati et al. (2014) (Tabel 1). Daging sapi diiris dengan ketebalan sekitar $5 \mathrm{~mm}$ dan dibumbui selama 12 jam. Setelah itu dikeringkan di dalam oven pada suhu $60^{\circ} \mathrm{C}$ selama 3 jam, dan dibalik sedemikian rupa sehingga bagian bawah sisi dalam posisi di atas, dan pengeringan dilanjutkan pada $70^{\circ} \mathrm{C}$ selama 5 jam (Suryati et al., 2014), setelah dikeringkan dendeng disimpan pada suhu kamar selama 24 jam. Sampel dendeng yang akan di analisa ditumbuk dan dihomogenkan dengan menggunakan blender. Sampel kemudian di analisa secara mikrobiologi dan fisikokimia.

\section{Analisis Mikrobiologi}

Analisis mikrobiologi dendeng sapi dengan penambahan simplisia serbuk jahe merah meliputi Analisis Angka Lempeng Total/Total Plate Count (TPC) dengan menggunakan metode Bacteriological Analitical Manual (BAM) (Food and Drug Administration, 2001) untuk penetapan jumlah koloninya, Analisis Escherichia coli dengan metode yang digunakan oleh Badan Standar Nasional (2008) yaitu dengan melihat dan menghitung jumlah koloni yang tampak hijau metalik, dan Analisis Staphylococcus aureus juga dengan metode yang digunakan oleh Badan Standar Nasional (2013).

\section{Analisis Fisikokimia}

Analisis fisikokimia dendeng sapi dengan penambahan simplisia serbuk jahe merah dengan menentukan jumlah komponen tertentu dalam suatu zat sampel yang meliputi nilai $\mathrm{pH}$, water activity $\left(\mathrm{a}_{\mathrm{W}}\right)$, analisis kandungan Malonaldehida (MDA) dilakukan dengan destilasi mengikuti prosedur Sørensen and Storgaard Jørgensen (1996) yaitu menghitung nilai TBARS (thiobarbituric acid reactive substances) menggunakan spektrofotometer pada $532 \mathrm{~nm}$. Analisis aktivitas antioksidan menggunakan metode yang digunakan oleh Tangkanakul et al. (2009) yaitu dengan mengekstraksi sampel dengan menggunakan $100 \%$ metanol pada suhu ruang yang hasil filtrasinya disaring lalu disimpan dalam wadah dan disimpan dalam freezer kemudian dihitung kapasitas antioksidannya yang ditentukan berdasarkan kemampuan ekstrak sampel dalam meredam radikal bebas DPPH dibandingkan terhadap antioksidan. Seluruh sampel di analisa secara duplo.

\section{Rancangan Percobaan dan Data}

Rancangan dalam penelitian ini menggunakan desain rancangan acak kelompok pola (RAK) dengan 5 perlakuan penambahan persentase pemberian simplisia serbuk jahe merah sebesar $0 \%, 5 \%, 10 \%, 15 \%$, dan $20 \%$ dengan 3 periode pembuatan yang berbeda, sedangkan peubah yang diamati adalah karakteristik mikrobiologi, dan fisikokimia. Model persamaan dalam rancangan menggunakan model Steel and Torrie (1980). Sedangkan data diolah dengan menggunakan program SAS 9.4.

Tabel 1. Formulasi pembuatan dendeng dengan penambahan simplisia serbuk jahe merah

\begin{tabular}{lccccc}
\hline \multirow{2}{*}{ Perlakuan } & \multicolumn{5}{c}{ Formula Berat $(\mathrm{g})$} \\
\cline { 2 - 6 } & $\mathrm{R} 0(0 \%)$ & $\mathrm{R} 1(5 \%)$ & $\mathrm{R} 2(10 \%)$ & $\mathrm{R} 3(15 \%)$ & $\mathrm{R} 4(20 \%)$ \\
\hline Daging Sapi & 1000 & 1000 & 1000 & 1000 & 1000 \\
Simplisia Serbuk Jahe Merah & 0 & 50 & 100 & 150 & 200 \\
Garam & 25 & 25 & 25 & 25 & 25 \\
Lengkuas & 85 & 85 & 85 & 85 & 85 \\
Ketumbar & 20 & 20 & 20 & 20 & 20 \\
Bawang Putih & 100 & 100 & 100 & 100 & 100 \\
Gula Merah & 165 & 165 & 165 & 165 & 165 \\
Gula & 165 & 165 & 165 & 165 & 165 \\
Asam Jawa & 3 & 3 & 3 & 3 & 3 \\
Lada & 3 & 3 & 3 & 3 & 3 \\
\hline Suyyyyy
\end{tabular}

Sumber : (Suryati et al., 2014) 


\section{Hasil dan Pembahasan \\ Kualitas Mikrobiologi}

Hasil pengujian karakteristik mikrobiologi meliputi total bakteri, total Escherichia coli dan total Staphylococcus aureus disajikan pada Tabel 2. Hasil yang didapatkan berbeda nyata pada pengujian TPC $(\mathrm{P}<0,05)$, sedangkan pada pengujian Escherichia coli, dan Staphylococcus aureus tidak terdapat kedua bakteri tersebut .

Hal ini menandakan bahwa pada setiap perlakuan (R0, R1, R2, R3, dan R4) tidak terdapat bakteri Escherichia coli, dan Staphylococcus aureus, hanya saja pada pengujian total bakteri terdapat jumlah bakteri dengan rataan nilai tertinggi yaitu 4,75 Log CFU/g pada perlakuan R0 (tanpa penambahan simplisia serbuk jahe merah) sedangkan nilai rataan terendah yaitu 4,15 Log CFU/g pada perlakuan R4. Hal tersebut masih dikategorikan aman untuk dikonsumsi sesuai dengan syarat mutu yang ditetapkan oleh (Badan Standarisasi Nasional, 2013) yaitu maksimal 5,00 Log $\mathrm{CFU} / \mathrm{g}$. Selain itu, baik perlakuan yang ditambahkan simplisia serbuk jahe merah maupun yang tidak ditambahkan simplisia serbuk jahe merah masih aman di konsumsi dikarenakan juga dipengaruhi oleh formula pembuatan produk (dendeng) yang menggunakan bumbu-bumbu tradisional, seperti yang diungkapkan oleh Soeparno (2015) bahwa penambahan bumbu dan garam dalam produk olahan daging memiliki fungsi sebagai pengawet yang dapat menghambat pertumbuhan mikroba.

Hal ini juga menindikasikan bahwa pada setiap penambahan simplisia serbuk jahe merah pada produk dendeng dapat menurunkan jumlah bakteri bahkan pada bakteri Escherichia coli dan Staphylococcus aureus tidak terdapat pada keseluruhan produk yang di teliti, dikarenakan sifat jahe yang dapat melakukan penghambatan terhadap aktifitas mikroba, seperti yang diungkapkan oleh Gao and Zhang (2010) ekstrak organik jahe kering dan jahe olahan memiliki efek penghambatan bakteri. Selain itu senyawa aktif yang terkandung pada jahe seperti gingerol dan shogaol memiliki aktifitas antimikroba (Giriraju \& Yunus, 2013).

\section{Pengujian Fisikokimia \\ Nilai pH.}

Hasil yang didapatkan dari nilai $\mathrm{pH}$ dendeng yang ditambahkan simplisia serbuk jahe merah memiliki nilai yang berbeda nyata (Tabel 3), yang memiliki nilai $\mathrm{pH}$ kisaran rataan 5,79 sampai dengan 6,08 dengan perlakuan $\mathrm{R} 4$ yang paling tinggi dengan rataan nilai $\mathrm{pH}$ nya yaitu 6,08 dan rataan nilai $\mathrm{pH}$ paling rendah 5,79 pada perlakuan R0. Angka tersebut masih lebih tinggi dari nilai $\mathrm{pH}$ yang dikemukakan oleh Suryati et al. (2012) bahwa $\mathrm{pH}$ dendeng dari produsen di Jawa Barat dan Jawa Tengah yang belum melalui proses penggorengan besaran nilai $\mathrm{pH}$ nya berkisar antara 5,13 sampai dengan 5,66.

Tabel 2. Karakteristik mikrobiologi dendeng yang ditambahkan simplisia serbuk jahe merah

\begin{tabular}{cccccc}
\hline Pengujian & \multicolumn{5}{c}{ Perlakuan Penambahan Simplisia Serbuk Jahe Merah } \\
\cline { 2 - 6 } Mikrobiologi & R0 (0\%) & R1 (5\%) & R2 (10\%) & R3 (15\%) & R4 (20\%) \\
\hline $\begin{array}{c}\text { Total Plate Count } \\
\text { (Log CFU/g) }\end{array}$ & $4,74 \pm 0,01^{\text {a }}$ & $4,60 \pm 0,01^{\mathrm{b}}$ & $4,49 \pm 0,01^{\mathrm{c}}$ & $4,36 \pm 0,02^{\mathrm{d}}$ & $4,15 \pm 0,01^{\mathrm{e}}$ \\
\hline $\begin{array}{c}\text { Escherichia coli } \\
\text { (Log CFU/g) }\end{array}$ & - & - & - & - & - \\
\hline $\begin{array}{c}\text { Staphylococcus } \\
\text { aureus } \\
\text { (Log CFU/g) }\end{array}$ & - & - & - & - & - \\
\hline
\end{tabular}

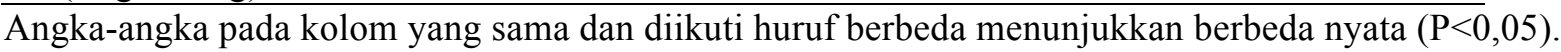

Tabel 3. Nilai pH dendeng yang ditambahkan simplisia serbuk jahe merah

\begin{tabular}{cccccc}
\hline \multirow{2}{*}{$\begin{array}{c}\text { Pengujian } \\
\text { Fisik }\end{array}$} & \multicolumn{5}{c}{ Perlakuan Penambahan Simplisia Serbuk Jahe Merah } \\
\cline { 2 - 6 } & $\mathbf{R 0}(\mathbf{0 \%})$ & $\mathbf{R 1}(\mathbf{5 \%})$ & $\mathbf{R 2}(\mathbf{1 0} \%)$ & $\mathbf{R 3}(\mathbf{1 5 \%})$ & $\mathbf{R 4}(\mathbf{2 0 \%})$ \\
\hline $\mathrm{pH}$ & $5,79 \pm 0,02^{\mathrm{c}}$ & $5,81 \pm 0,01^{\mathrm{c}}$ & $5,81 \pm 0,01^{\mathrm{c}}$ & $5,91 \pm 0,02^{\mathrm{b}}$ & $6,08 \pm 0,01^{\mathrm{a}}$
\end{tabular}

$\overline{\text { Angka-angka pada kolom yang sama dan diikuti huruf berbeda menunjukkan berbeda nyata }(\mathrm{P}<0}, 05)$. 
Nilai angka $\mathrm{pH}$ yang dihasilkan dalam penelitian ini tinggi disebabkan karena adanya penambahan bumbu-bumbu tradisional, hal lain yang menyebabkan nilai $\mathrm{pH}$ lebih tinggi dikarenakan adanya penambahan simplisia serbuk jahe merah pada perlakukan R1 sampai dengan perlakuan R4 dikarenakan kandungan gingerol dan shoagol dari jahe merah memiliki tingkat paling tinggi dibandingkan dengan varietas jenis jahe lainnya. Hal tersebut sesuai dengan pernyataan dari (Rafi et al., 2013) bahwa ketiga varietas jahe (emprit, gajah, dan merah) menunjukkan tingkat rasa pedasnya yang berbeda karena jumlah keton fenol homolog yang berbeda, yaitu 6-, 8-, 10-gingerol tiap varietasnya, dan 6-shogaol yang telah diidentifikasi sebagai senyawa utama dalam jahe. Oleh karena sebab itulah nilai $\mathrm{pH}$ sampel pun mengalami peningkatan seiring dengan peningkatan pemberian simplisia serbuk jahe merahnya, hal ini sesuai dengan pendapat (Nair, 2019) bahwa kandungan simplisia serbuk jahe merah berkisar antara 5,5-6,5, dan juga pendapat dari (Lentera, 2002) $\mathrm{pH}$ jahe merah berkisar sekitar 4,3-7,4 dengan $\mathrm{pH}$ optimum 6. Sedangkan pendapat dari (Shirshir et al., 2012) bahwa komposisi pH dari bubuk jahe sebesar 5 .

\section{Pengujian Aktifitas Air $\left(a_{w}\right)$}

Hasil yang didapatkan dari pengujian aktifitas air menunjukkan hasil yang sangat berbeda nyata $(p<0,05)$ karena nilai rataan berada pada kisaran 0,57 sampai dengan 0,79 dengan nilai $\mathrm{a}_{\mathrm{w}}$ paling tinggi pada perlakuan $\mathrm{R} 1$ yaitu 0,79 dan nilai $a_{w}$ paling rendah yaitu 0,57 pada perlakuan R4 (Tabel.4). Nilai tersebut masih berada pada kisaran nilai $\mathrm{a}_{\mathrm{w}}$ yang dikemukan oleh Purnomo (1986) bahwa hasil laboratorium dari produk dendeng memiliki nilai aktivitas air $\left(\mathrm{a}_{\mathrm{w}}\right)$ adalah 0,57 dan 0,60. Hasil tersebut disebabkan karena pada setiap penambahan simplisia serbuk jahe merah mengurangi nilai $\mathrm{a}_{\mathrm{w}}$, terutama pada perlakuan $\mathrm{R} 4$, hanya saja untuk perlakuan R1 yang menggunakan penambahan simplisia serbuk jahe merah $5 \%$ cukup tinggi nilai $a_{w}$ nya dibandingkan dengan perlakuan lainnya, dikarenakan penambahan simplisia serbuk jahenya yang kecil dibawah 10\% dibandingkan dengan perlakuan lainnya, hal ini disebabkan karena penggunaan simplisia serbuk jahe yang memiliki karaterisitik fisik berbentuk bubuk yang lebih padat yang menyebabkan aktifitas air juga berkurang seiring dengan jumlah penambahannya, selain itu juga disebabkan masih dipengaruhi oleh bumbu-bumbu lain yang masih lebih tinggi daripada penambahan simplisia serbuk jahenya seperti halnya pada perlakuan R0 yang tanpa ditambahkan simplisia serbuk jahe merah. Hasil tersebut juga sesuai dengan pendapat (Suantika et al., 2018) bahwa jahe yang mengandung enzim zingibain sehingga nilai $a_{w}$ semakin meningkat, peningkatan $\mathrm{a}_{\mathrm{w}}$ disebabkan adanya perubahan pada lemak dan protein dalam daging yang diakibatkan oleh enzim proteolitik yang bersumber dari jahe.

Selain itu, hal yang sama juga dijelaskan oleh Saputro (2016) bahwa aktifitas air $\left(\mathrm{a}_{\mathrm{w}}\right)$ dari produk jadi (oven dendeng sapi kering) berkisar antara 0,57 dan 0,68 yang diharapkan dapat menghambat pertumbuhan pembusukan dan bakteri patogen. Kebanyakan bakteri pembusuk tidak akan tumbuh di bawah $\mathrm{a}_{\mathrm{w}}$ dari 0,91 dan bersifat patogen bakteri seperti Staphylococcus aureus dibatasi oleh $\mathrm{a}_{\mathrm{w}} 0,86$ (Jay et al., 2006).

\section{Pengujian thiobarbituric acid reactive substances (TBARS)}

Hasil perolehan nilai thiobarbituric acid reactive substances (TBARS) pada penelitian ini berpengaruh nyata $(p<0,05)$ terhadap seluruh perlakuan, baik yang tidak ditambahkan simplisia serbuk jahe merah maupun yang ditambahkan simplisia serbuk jahe merah, sedangkan hasil dari keseluruhan perlakuan yang ditambahkan simplisia serbuk jahe merah terhadap perlakuan yang tidak ditambahkan simplisia serbuk jahe merah memiliki hasil yang tidak berpengaruh nyata $(p>0,05)$, terlebih dari rataan nilai TBARS yang paling rendah pada perlakuan R4 yaitu 0,32 $\mathrm{mg} / \mathrm{kg}$ dengan penambahan simplisia serbuk jahe merah paling tinggi yaitu sebesar $20 \%$, sedangkan rataan nilai TBARS yang paling tinggi pada perlakuan R0 yaitu $0,81 \mathrm{mg} / \mathrm{kg}$ dengan tanpa penambahan simplisia serbuk jahe merah (Tabel 5). Penentuan nilai TBARS dilakukan untuk menilai tingkat oksidasi lipid (Ohkawa et al., 1979). 
Tabel 4. Nilai $\mathrm{a}_{\mathrm{w}}$ dendeng yang ditambahkan simplisia serbuk jahe merah

\begin{tabular}{cccccc}
\hline $\begin{array}{c}\text { Pengujian } \\
\text { Fisik }\end{array}$ & \multicolumn{5}{c}{ Perlakuan Penambahan Simplisia Serbuk Jahe Merah } \\
\cline { 2 - 6 } & R0 (0\%) & R1 (5\%) & R2 (10\%) & R3 (15\%) & R4 (20\%) \\
\hline $\mathrm{a}_{\mathrm{w}}$ & $0,70 \pm 0,01^{\mathrm{b}}$ & $0,79 \pm 0,01^{\mathrm{a}}$ & $0,60 \pm 0,01^{\mathrm{c}}$ & $0,67 \pm 0,03^{\mathrm{b}}$ & $0,57 \pm 0,00^{\mathrm{c}}$
\end{tabular}

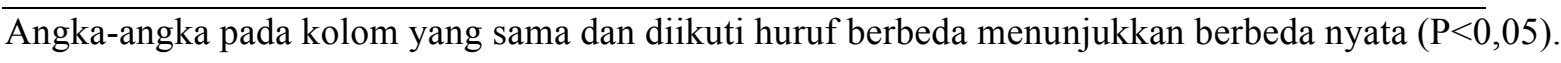

Tabel 5. Nilai TBARS dendeng yang ditambahkan simplisia serbuk jahe merah

\begin{tabular}{cccccc}
\hline \multirow{2}{*}{$\begin{array}{c}\text { Pengujian } \\
\text { Kimia }\end{array}$} & \multicolumn{5}{c}{ Perlakuan Penambahan Simplisia Serbuk Jahe Merah } \\
\cline { 2 - 5 } & $\mathbf{R 0}(\mathbf{0} \%)$ & $\mathbf{R 1}(\mathbf{5 \%})$ & $\mathbf{R 2}(\mathbf{1 0} \%)$ & $\mathbf{R 3}(\mathbf{1 5 \%})$ & $\mathbf{R 4}(\mathbf{2 0 \%})$ \\
\hline $\begin{array}{c}\text { Thiobarbituric } \\
\text { Acid Reactive } \\
\begin{array}{c}\text { Substances } \\
\text { (TBARS) } \mathrm{mg} / \mathrm{kg}\end{array}\end{array}$ & $0,81 \pm 0,24^{\mathrm{a}}$ & $0,55 \pm 0,11^{\mathrm{b}}$ & $0,50 \pm 0,01^{\mathrm{b}}$ & $0,41 \pm 0,03^{\mathrm{b}}$ & $0,32 \pm 0,03^{\mathrm{b}}$ \\
\hline
\end{tabular}

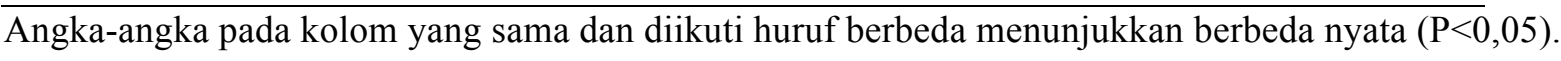

Hal ini disebabkan dengan penambahan simplisia serbuk jahe merah nilai TBARS mengalami penurunan kadar pada setiap perlakuan dibandingkan dengan perlakuan kontrol, karena di dalam kandungan jahe termasuk jahe merah memiliki kandungan gingerol yang menghambat oksidasi lipid pada sampel. Ini membuktikan bahwa jahe merah mampu menurunkan nilai TBARS dibandingkan yang tanpa perlakuan, hal tersebut sesuai dengan pendapat Pulla Reddy and Lokesh (1992) bahwa Gingerol yang berasal dari jahe, pada konsentrasi tinggi, menghambat kompleks askorbat-besi yang pada gilirannya menginduksi peroksidasi lipid. Setelah peroksidasi, peroksida lipid menguraikan dan memecah produk, seperti Malonaldehida (MDA) (Mattje et al., 2019).

\section{Pengujian Antioksidan}

Hasil pengujian aktifitas antioksidan dari sampel dendeng yang yang ditambahkan simplisia serbuk jahe merah memiliki hasil yang berpengaruh nyata $(\mathrm{P}<0,05)$ pada nilai rataan perlakuan $\mathrm{R} 4$ yang paling tinggi yaitu 429,22 $\mathrm{mgVCE} / \mathrm{g}$ dengan penambahan simplisia serbuk jahe merah paling tinggi, sedangkan nilai rataan paling rendah ada pada perlakuan kontrol atau perlakuan R0 yang tidak ada penambahan simplisia serbuk jahe merah dengan nilai 183,28 $\mathrm{mgVCE} / \mathrm{g}$, dari hasil yang ada pada Tabel 5 terlihat bahwa nilai rataan yang diperoleh setiap perlakuan mengalami peningkatan angka antioksidannya setiap penambahan simplisia serbuk jahe merah dengan nilai keseluruhan dari setiap perlakuan yang ditambahkan simplisia serbuk jahe merah untuk angka antioksidannya masih lebih tinggi dibandingkan dengan angka antioksidan dari perlakuan tanpa penambahan simplisia serbuk jahe merah (R0). Nilai yang di peroleh memiliki tingkatan antioksidan yang tinggi, hal ini sesuai dengan pendapat (Tangkanakul et al., 2009) bahwa kapasitas antioksidan dibagi menjadi empat kelompok: sangat tinggi ( $>500$ $\mathrm{mgVCE} / \mathrm{g})$, tinggi $(200-500 \mathrm{mgVCE} / \mathrm{g})$, sedang (100-200 $\mathrm{mgVCE} / \mathrm{g})$, dan rendah $(<100$ $\mathrm{mgVCE} / \mathrm{g})$.

Selain itu untuk aktivitas penghambat DPPH berkisar $48,39 \%$ - 88,77\%, hal ini dikarenakan penambahan simplisia serbuk jahe yang mampu menghambat DPPH lebih tinggi dari perlakuan kontrol, dengan demikian semakin meningkatnya penambahan simplisia serbuk jahe merah maka semakin tinggi daya hambat DPPH, hal tersebut sesuai dengan pendapat (Suryati et al., 2014) bahwa aktivitas penghambatan DPPH berkisar 21.06\%$62.91 \%$.

Hal tersebut juga disebabkan adanya penambahan bumbu-bumbu tradisional yang dapat menurunkan angka nilai antioksidan dari sampel, seperti yang diungkapkan oleh (Tangkanakul et al., 2009) bahwa aktivitas antioksidan berasal dari total fenolik, yang terutama dari berbagai bumbu dan rempahrempah yang digunakan sebagai bahan. Selain itu, yang menyebabkan setiap perlakuan dengan penambahan simplisia serbuk jahe merah mengalami peningkatan nilai antioksidannya dikarenakan kandungan jahe merahnya yang memang memiliki kandungan 
Tabel 6. Nilai Antioksidan dendeng yang ditambahkan simplisia serbuk jahe merah

\begin{tabular}{|c|c|c|c|c|c|}
\hline \multirow{2}{*}{$\begin{array}{c}\text { Pengujian } \\
\text { Kimia }\end{array}$} & \multicolumn{5}{|c|}{ Perlakuan Penambahan Simplisia Serbuk Jahe Merah } \\
\hline & R0 (0\%) & R1 (5\%) & R2 (10\%) & R3 (15\%) & R4 (20\%) \\
\hline $\begin{array}{l}\text { Antioksidan } \\
(\mathrm{mgVCE} / \mathrm{g})\end{array}$ & $\underline{183,28+1,98^{\mathrm{e}}}$ & $413,13+1,48^{\mathrm{d}}$ & $416,48 \pm 1,12^{\mathrm{c}}$ & $420,76+1,23^{b}$ & $429,22 \pm 1,96^{\mathrm{a}}$ \\
\hline $\begin{array}{l}\text { Aktifitas } \\
\text { Penghambat } \\
\text { DPPH } \\
(\%)\end{array}$ & $48,39 \pm 0,32^{\mathrm{e}}$ & $86,13 \pm 0,24^{\mathrm{d}}$ & $86,68 \pm 0,18^{\mathrm{c}}$ & $87,38 \pm 0,20^{\mathrm{b}}$ & $88,77 \pm 0,32^{\mathrm{a}}$ \\
\hline
\end{tabular}

$\overline{\text { Angka-angka pada kolom yang sama dan diikuti huruf berbeda menunjukkan berbeda nyata }(\mathrm{P}<0,05)}$.

antioksidan, seperti kandungan shoagol yang ada pada jahe. Shogaol telah terbukti menjadi senyawa dengan aktivitas antioksidan tinggi (Nair, 2019). Selain gingerol dan shogaol, jahe merah sarat dengan anthocyanin dan tannin (Wen-Guang et al., 2001). Juga, kandungan flavonoid jahe merah jauh lebih tinggi daripada jenis jahe lainnya. Menurut Ami et al. (2003) Jahe merah memiliki Polifenol alami dapat menghilangkan radikal bebas, katalis logam khelat, mengaktifkan enzim antioksidan, mengurangi radikal tokoferol, dan menghambat oksidasi. Ini membuktikan bahwa sampel dengan penambahan simplisia serbuk jahe merah nilai aktifitas antioksidannya akan makin tinggi dibandingkan dengan sampel yang tidak ditambahkan simplisia serbuk jahe merah, dikarenakan kandungan kimianya.

\section{Kesimpulan}

Dendeng sapi dengan penambahan simplisia serbuk jahe merah memiliki aktifitas mikroba yang masih aman untuk dikonsumsi, sedangkan nilai $\mathrm{pH}$ dan aktifitas air yang didapatkan masih dalam standar yang ditetapkan, untuk nilai MDA dan aktioksidan memiliki perbedaan pada perlakuan kontrol dengan nilai yang lebih tinggi dibandingkan dengan dendeng yang ditambahkan simplisia serbuk jahe merah. Pada dasarnya keseluruhan perlakuan dendeng sapi yang ditambahkan simplisia serbuk jahe merah sampai level penambahan $20 \%$ masih aman untuk dikonsumsi dan masih dalam standar yang ditetapkan.

\section{Daftar Pustaka}

Ami, D., Davidovi, D., \& Trinajsti, N. (2003). Structure-Radical Scavenging Activity Relationships of Flavonoids. 76(1), 5561.

Badan Standarisasi Nasional. (2008). SNI 3932:2008 - Mutu Karkas dan Daging
Sapi. 1-14.

Badan Standarisasi Nasional. (2013). SNI 2908:2013 - Dendeng Sapi. Bsn 2013, 140.

Direktorat Jenderal Peternakan dan Kesehatan Hewan. (2017). STATISTIK PETERNAKAN DAN KESEHATAN HEWAN 2017. Direktorat Jenderal Peternakan dan Kesehatan Hewan Kementerian Pertanian RI.

Food and Drug Administration. (2001). Bacteriological Analytical Manual (8th, Revis ed.). AOAC Inc.

Gao, D., \& Zhang, Y. (2010). Comparative antibacterial activities of extracts of dried ginger and processed ginger. Pharmacognosy Journal, 2(15), 41-44. https://doi.org/10.1016/S09753575(10)80077-X

Giriraju, A., \& Yunus, G. Y. (2013). Assessment of Antimicrobial Potential of $10 \%$ Ginger Extract Against Streptococcus mutans, Candida albicans, and Enterococcus faecalis: An in vitro study. Indian Journal of Dental Research, 24(4), 397-400. https://doi.org/10.4103/09709290.118356

Jay, J. M., Loessner, M. J., \& Golden, D. A. (2006). Modern Food Microbiology. In Spinger (Vol. 56, Issue 1). https://doi.org/10.1007/bf03174975

Lentera, T. (2002). Khasiat dan Manfaat Jahe Merah: Si Rimpang Ajaib (Mulyono (ed.)). Agro Media Pustaka.

Mattje, L. G. B., Tormen, L., Bombardelli, M. C. M., Corazza, M. L., \& Bainy, E. M. (2019). Ginger essential oil and supercritical extract as natural antioxidants in tilapia fish burger. Journal of Food Processing and Preservation, 43(5), $1-8$. https://doi.org/10.1111/jfpp.13942 
Nair, K. P. (2019). Turmeric ( Curcuma longa L.) and Ginger (Zingiber o cinale Rosc.) - World's Invaluable Medicinal Spices The Agronomy and Economy of Turmeric. Spinger.

https://doi.org/doi.org/10.1007/978-3030-29189-1

Ohkawa, H., Ohishi, N., \& Yagi, K. (1979). Assay for lipid peroxides in animal tissues by thiobarbituric acid reaction. Analytical Biochemistry, 95(2), 351-358. https://doi.org/10.1016/00032697(79)90738-3

Pulla Reddy, A. C., \& Lokesh, B. R. (1992). Studies on spice principles as antioxidants in the inhibition of lipid peroxidation of rat liver microsomes. Molecular and Cellular Biochemistry, 111(1-2), 117124. https://doi.org/10.1007/BF00229582

Purnomo, H. (1986). Aspects of the Stability of Intermediate Moisture Meat. The University of New South Wales, Sydney, Australia.

Rafi, M., Lim, L. W., Takeuchi, T., \& Darusman, L. K. (2013). Simultaneous determination of gingerols and shogaol using capillary liquid chromatography and its application in discrimination of three ginger varieties from Indonesia. Talanta, 103, 28-32. https://doi.org/10.1016/j.talanta.2012.09. 057

Saputro, E. (2016). Formulation of Natural Curing in the Manufacturing of Dendeng Sapi - Indonesian Dried Beef from Local Beef Cattle. 502-513. https://doi.org/10.14334/proc.intsem.lpvt -2016-p.502-513

Shirshir, R. I., Hossain, M., \& Hossain, M. (2012). Processing of ginger powder. Bangladesh Research Publications Journal, 7(3), 277-282. https://www.researchgate.net/publication /308321567_PROCESSING_OF_GING ER POWDER

Soeparno. (2015). Ilmu dan Teknologi Daging. Cetakan Keenam (Edisi Revisi). Gadjah Mada University Press.

Sørensen, G., \& Storgaard Jørgensen, S. (1996). A critical examination of some experimental variables in the 2thiobarbituric acid (TBA) test for lipid oxidation in meat products. European Food Research and Technology, 202(3),
205-210.

https://doi.org/10.1007/bf01263541

Steel, R. G. D., \& Torrie, J. H. (1980). The Principles and Procedures of Statistics. McGraw-Hill, Inc.

Suantika, R., Suryaningsih, L., \& Gumilar, J. (2018). Pengaruh Lama Perendaman Dengan Menggunakan Sari Jahe Terhadap Kualitas Fisik (Daya Ikat Air, Keempukkan dan pH) Daging Domba "The Effect Of Soaking Time Use Ginger Juice To Sheep Meat Physical Quality (Water Holding Capacity, Tenderness And Ph)." Jurnal Ilmu Ternak Universitas Padjadjaran, $\quad$ 17(2), 67. https://doi.org/10.24198/jit.v17i2.15129

Sulistyani, N. (2018). Pendalaman Materi Farmasi Modul 006: Pengembangan Sediaan Obat Tradisional (Kementerian Pendidikan dan Kebudayaan Kementerian Riset , Teknologi dan Pendidikan Tinggi).

Suradi, K., Gumilar, J., Hemas, G., \& Yohana, R. (2017). Kemampuan Serbuk Serai ( Cymbopogon Citratus ) Menekan Peningkatan Total Bakteri Dan Keasaman ( Ph) Dendeng Domba Selama Penyimpanan "The Ability of Lemongrass Powder (Cymbopogon citarus) to Inhibit Total Bacteria and Acidity ( $p H)$ of Lamb Jerky During St. 17(2), 106-111.

Suryati, T., Astawan, M., Lioe, H. N., \& Wresdiyati, T. (2012). Curing Ingredients, Characteristics, Total Phenolic, and Antioxidant Activity of Commercial Indonesian Dried Meat Product (Dendeng). Media Peternakan, 35(2), 111-116. https://doi.org/10.5398/medpet.2012.35.2 .111

Suryati, T., Astawan, M., Lioe, H. N., Wresdiyati, T., \& Usmiati, S. (2014). Nitrite residue and malonaldehyde reduction in dendeng - Indonesian dried meat - influenced by spices, curing methods and precooking preparation. Meat Science, 96(3), 1403-1408. https://doi.org/10.1016/j.meatsci.2013.11 .023

Tangkanakul, P., Auttaviboonkul, P., Niyomwit, B., Lowvitoon, N., Charoenthamawat, P., \& Trakoontivakorn, G. (2009). Antioxidant capacity, total phenolic content and 
nutritional composition of Asian foods after thermal processing. International Food Research Journal, 16(4), 571-580.

Wen-Guang, L., Xiao-Yu, Z., Yong-Jie, W., \&

Xuan, T. (2001). Anti-inflammatory effect and mechanism of proanthocyanidins from grape seeds. In Acta Pharmacologica Sinica (Vol. 22, Issue 12, pp. 1117-1120). 